\begin{tabular}{c}
$\begin{array}{c}\text { Brazilian Journal } \\
\text { of Chemical } \\
\text { Engineering }\end{array}$ \\
\hline
\end{tabular}

ISSN 0104-6632

Printed in Brazil

www.abeq.org.br/bjche

Vol. 31, No. 02, pp. 365 - 371, April - June, 2014

dx.doi.org/10.1590/0104-6632.20140312s00002394

\title{
ELECTROREMEDIATION OF HEAVY METALS IN SEWAGE SLUDGE
}

\author{
C. Elicker ${ }^{*}$, P. J. Sanches Filho and K. R. L. Castagno \\ Department of Management and Environmental Sanitation, Phone: + (55) (53) 2123-1000, Fax: + (55) (53) 2123-1006, \\ Instituto Federal Sul-Rio-Grandense (IFSul), Praça Vinte de Setembro 455, CEP: 96015-360, Pelotas - RS, Brazil. \\ E-mail: carolinaelicker@yahoo.com.br
}

(Submitted: November 7, 2012 ; Revised: June 25, 2013 ; Accepted: June 26, 2013)

\begin{abstract}
This paper presents the application of electrokinetic remediation in the treatment of sludge in a sewage treatment station. The study consisted of, in a first step, the characterization of physicochemical parameters of sludge and, in a second step, the implementation of the electrokinetic remediation technique. The concentrations of $\mathrm{Cu}, \mathrm{Cr}, \mathrm{Pb}$ and $\mathrm{Zn}$ in sludge samples, before and after the experiment, were determined by atomic absorption spectroscopy. After 40 hours of experiment, considering an electrolyte flow-rate of 1.34 ${\mathrm{L} . \mathrm{h}^{-1}}$ at a voltage of $20 \mathrm{~V}$, the removal rate of all the metals accompanied was over $50 \%$; the highest removal efficiency was for $\mathrm{Pb}$, with $72.49 \%$. The results show the feasibility of using the electrochemical technique of electrokinetic remediation for metal removal from a sludge sewage treatment station.

Keywords: Metals; Sewage sludge; Electrokinetic remediation; Atomic absorption.
\end{abstract}

\section{INTRODUCTION}

Among the various types of contaminants, metals differ from toxic organic compounds because they are absolutely non-degradable, so they can accumulate in the components of the environment where they manifest their toxicity (Baird, 2002).

Many metals are essential to life. Generally the concentrations are expressed in ppm and nature takes care of providing the quantities needed to maintain healthy life. Other metals do not exercise known functions in the biological cycle. In both cases, the presence of increasing concentrations of metals in nature can make the tolerable levels become toxic (Tavares and Carvalho, 1992).

The Brazilian Association of Technical Standards (ABNT), in NBR 10004, classifies solid wastes contaminated by heavy metals as hazardous waste class I, since they represent serious risks to the environment and must be disposed properly.

Sewage is considered to be a hazardous waste and its treatment is required. Although there are several systems for treatment of this type of waste, all of them generate a subproduct called sewage sludge or biosolids, where all compounds and contaminants removed from the sanitary sewage will be present.

The most common solution is the use of landfills for disposal of sewage sludge; however, this implies risks to bodies of water and to public health, in addition to operational difficulties and costs. Hence, this is considered to be a problematic solution. One alternative that is conquering more space for the disposal of sewage sludge is its use as a fertilizer. For this, the sewage sludge should contain concentrations of heavy metals and pathogens below the limits set by the National Environment Council (CONAMA), according to Resolution 375/2006.

For removal of metals from environmental compartments and waste liquids and solids, several techniques have been developed, and the most traditional technologies available for wastes treatments are physical, chemical, biological and electrochemical processes.

In the last decade the electrochemical treatment has been frequently applied for removal of organic

*To whom correspondence should be addressed 
compounds and metals both liquid and solid waste, soils and sediments (Pamukcu and Wittle, 1992; Zhongming et al., 1996; Thaveemaitree et al., 2003). The electrolytic process for the removal/recovery of metals is an alternative to traditional chemical methods, since it has advantages such as: minimum risk of violent reactions or toxic emissions; involves no addition of toxic chemicals; allows the recovery of metals present in solution; not restricted to the treatment of inorganic species, and is also employed for oxidation of organic compounds, and present a competitive operational cost when compared with other processes (Rajeshwar and Ibanez, 1997).

Electrokinetic remediation uses an electrical current to mineralize organic compounds, and to mobilize and remove metal contaminants from soils or sediments. The technique consists of the application of an electrical field gradient between electrodes for the extraction and migration of contaminants by electrokinetic transport mechanisms. This electric field generates transport processes of ions and pore fluids and electrically charged particles, promoting the extraction of contaminants (Schmidt, 2004). Many reactions/interactions between soil and contaminants can happen, including: reactions at the electrodes, adsorption/desorption, electrophoresis and structural modifications of the particle contaminated matrix (Rutigliano et al., 2008).

Electrokinetic remediation is based on three principal mechanisms: electromigration of ionic species, electroosmosis and electrophoresis (Acar and Alshawabkeh, 1993). Electromigration is the migration of charged species present in the soil void water in an electric field. Cations move toward the cathode, while anions move toward the anode. Electroosmosis in a pore occurs because of the drag interaction between the bulk of the liquid in the pore and a thin layer of charged fluid next to the pore wall that, like a single ion, moves under the action of the electric field in a direction parallel to it. The thin layer of charged fluid, or electric double layer, has a typical thickness between 1 and $10 \mathrm{~nm}$ (Probstein and Hicks, 1993). Electroosmosis produces a rapid flow of water in low-permeability soils and probably contributes significantly to the decontamination process in clay soils. Electrophoresis is the migration of charged colloids in a soil-liquid mixture. In some cases, electrophoresis may play a role in decontamination if the migrating colloids have the contaminants adsorbed on them (Pamukcu and Wittle, 1992).

According to Niroumand et al. (2012), electrokinetics may be an appropriate remediation technique in sediment remediation based on its advantages: (a) it allows treatment of inorganic and organic compounds in porous media simultaneously; (b) the $\mathrm{pH}$ shift produced by the electrolysis of water effectively desorbs contaminating ions; (c) it is an effective method of inducing the movement of water, ions, and colloids through fine-grained sediment; (d) it is competitive in cost and remediation effectiveness to other methods currently in use. Furthermore, it allows the simultaneous removal of different heavy metals, with high efficiency of removal in a short time, and the recovery of metals, which is not suitable for some other remediation technologies such as soil incineration and bioremediation.

Several studies of electrokinetic remediation techniques have been made in the last years to remove various contaminants. In these studies, many factors influencing the efficiency of removal of contaminants were monitored, such as: physical-chemical characteristics of the contaminated material, concentration of the contaminant, $\mathrm{pH}$, potential, time and different enhancing electrolytes (Guaracho, 2005; Kim et al, 2011; Matsumoto et al., 2007; Pedrazzoli, 2004; Rozas and Castellote, 2012; Rutigliano et al., 2008).

Despite the good results obtained with electrokinetic remediation techniques in the laboratory studies, most of them were limited to experiments conducted on commercially available clay minerals by introducing various contaminants. Considering this fact, this paper presents the use of an electrokinetic remediation technique for removal of heavy metals from sludge generated in an effluent treatment station, in order to meet the demands of the productive sector for alternatives that eliminate or minimize the environmental impact caused by wastes contaminated by heavy metals.

\section{EXPERIMENTAL}

\section{Collection and Preparation of Samples}

The study was performed using the sludge generated in the Anaerobic Fluidized Bed Reactor (RALF) of the Sewage Treatment Station (ETE) in the city of Pelotas/RS. The collection was performed in November, 2010, on a day of low humidity and a temperature of $25^{\circ} \mathrm{C}$. Samples were collected with the use of a shovel at several points of the middle layer of the drying bed. They were placed in plastic containers and stored under refrigeration at a temperature of $\pm 4{ }^{\circ} \mathrm{C}$ until their use. Sludge samples were kiln dried at $60{ }^{\circ} \mathrm{C}$ for 48 hours. After, they were macerated in a mortar and sieved. The fraction $<63 \mu \mathrm{m}$ was used for the determination of organic carbon, total nitrogen and for the chemical treatment. 


\section{Samples Characterization}

Analyses were performed in triplicate, being characterized by the physical-chemical aspects (moisture, $\mathrm{pH}$ and $\mathrm{C} / \mathrm{N}$ ratio) and concentration of the metals copper, lead, chromium and zinc.

To measure the $\mathrm{pH}$, a aliquot of $10 \mathrm{~cm}^{3}$ of the sludge was diluted in $10 \mathrm{~mL}$ of distilled water. The measurement was performed with a Digimed DM21 digital pHmeter. The moisture determination was made as proposed by Tedesco et al. (1995). The organic carbon was determined by calcination as mentioned in Dias and Lima (2004). Nitrogen was determined by the Kjeldahl method.

The chemical treatment for pseudo-total extraction refers to the extraction of all of the bioavailable fractions of metals. This treatment consisted of a modification of the procedure proposed by Hortellani et al. (2008). To a sample of $2 \mathrm{~g}$ was added $4 \mathrm{~mL}$ of aqua regia, $4 \mathrm{~mL}$ of Milli-Q water and $1 \mathrm{~mL}$ of perchloric acid. The mixture was heated in a water bath at $90{ }^{\circ} \mathrm{C}$ for 30 minutes. The resulting solution was filtered through a qualitative filter paper, transferred to a $50 \mathrm{ml}$ volumetric flask, and the volume completed with distilled water. The extracts were subjected to analysis by Flame Atomic Absorption Spectrometry, in a PerkinElmer Model AAnalyst 200 spectrophotometer, whose operating conditions are described in Table 1.

Table 1: Operational conditions of the atomic absorption spectrometer used for metal analysis.

\begin{tabular}{|l|c|c|c|c|}
\hline & $\begin{array}{c}\text { Wavelength } \\
\text { (nm) }\end{array}$ & $\begin{array}{c}\text { Gap } \\
\text { (nm) }\end{array}$ & $\begin{array}{c}\text { Oxidant } \\
\text { flow } \\
\text { (L.min }^{-1} \text { ) }\end{array}$ & $\begin{array}{c}\text { Acetylene } \\
\text { flow } \\
\left(\text { L.min }^{-1} \text { ) }\right.\end{array}$ \\
\hline Cooper & 327.4 & $2.7 / 0.8$ & 10 & 3.3 \\
Chromium & 357.9 & $2.7 / 0.8$ & 10 & 2.5 \\
Lead & 217 & $2.7 / 1.3$ & 10 & 2.5 \\
Zinc & 213.9 & $2.7 / 1.8$ & 10 & 2.5 \\
\hline
\end{tabular}

\section{Electroremediation Assays}

The electroremediation assays were performed in an electrochemical cell whose schematic drawing is shown in Figure 1. The electrochemical cell was constructed in acrylic, in the dimensions of $10 \times 25.5 \times$ $5.5 \mathrm{~cm}$, with two graphite rods as anode and a stainless steel plate as cathode $(23 \mathrm{~cm} \times 5.5 \mathrm{~cm} \times 0.15 \mathrm{~cm})$. The distance between the anode and cathode was kept constant at $6 \mathrm{~cm}$. A $100 \mathrm{~g}$ sample of sludge was maintained between the electrodes by using two perforated acrylic brackets, both covered by qualitative filter paper.

The system used an electrolyte solution of 0.025 mol. $\mathrm{L}^{-1}$ sodium chloride $(\mathrm{NaCl})$, with a flow rate of $1.34 \mathrm{~L} \mathrm{~h}^{-1}$, in order to minimize the medium resistivity and to promote ionic conductivity of species. The system operated under a constant voltage of $20 \mathrm{~V}$ and a current of $100 \mathrm{~mA}$. The experiment lasted 40 hours ( 8 hours per day for 5 consecutive days).

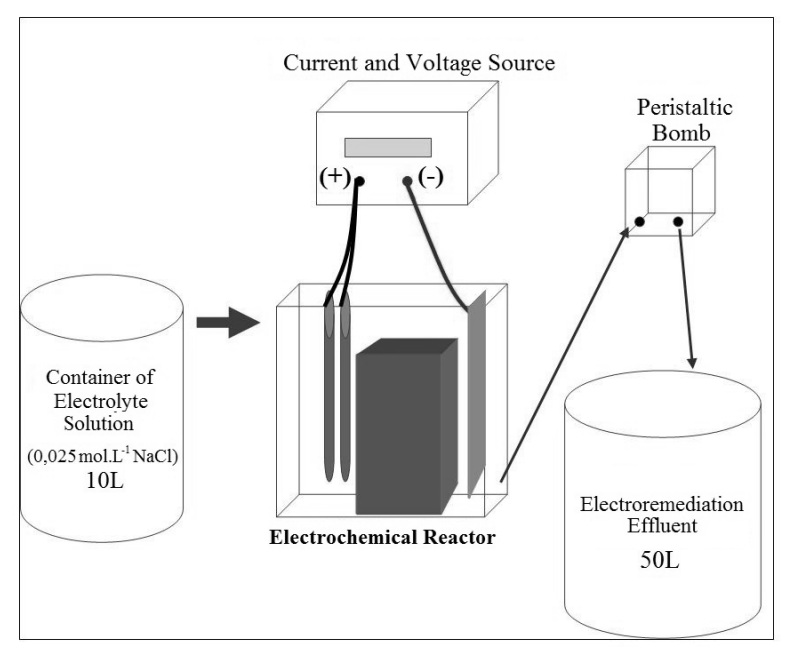

Figure 1: Schematic representation of the system used.

Samples of the sludge and the cathodic electrolyte solution were collected at the end of each day of the experiment. The sludge samples were subjected to chemical treatment for extraction of metals and the cathodic electrolytic solution samples subjected to $\mathrm{pH}$ determination.

\section{RESULTS AND DISCUSSION}

\section{Sample Characterization}

The values determined in the characterization as well as their relative standard deviations (RSD) in percentage are shown in Table 2. All values are considered to be acceptable. The values determined for lead, copper, chromium and zinc (mg. $\mathrm{kg}^{-1}$ on a dry basis), and their RSD (\%) are shown in Table 3. All values found are within the maximum permissible concentration, according to CONAMA Resolution No. $375 / 2006$. 
Table 2: Physical-chemical characteristics of the sludge studied and the respective RSD (\%). ${ }^{1}$ measured at $29.2{ }^{\circ} \mathrm{C}$; ${ }^{2}$ approximate value.

\begin{tabular}{|c|c|c|c|c|c|}
\hline & pH & $\begin{array}{c}\text { Moisture } \\
(\%)\end{array}$ & $\begin{array}{c}\text { Carbon } \\
\text { (ppm) }\end{array}$ & $\begin{array}{c}\text { Nitrogen } \\
\text { (ppm) }\end{array}$ & $\mathbf{C} / \mathbf{N}$ \\
\hline Sewage Sludge & $5.71^{1}$ & $67.49 \pm 4.14$ & $28.48 \pm 2.73$ & $3.28 \pm 1.37$ & $9: 1^{2}$ \\
\hline
\end{tabular}

Table 3: Concentration (mg.kg $\left.{ }^{-1}\right)$ on a dry basis of the metals monitored in the sludge studied, before and after electrokinetic remediation, and the respective RSD (\%), as well as the maximum allowable

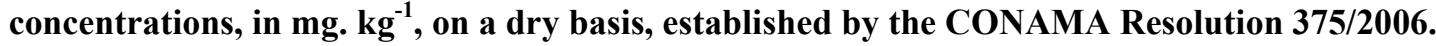

\begin{tabular}{|l|c|c|c|c|}
\hline & Copper & Chromium & Lead & Zinc \\
\hline Sewage Sludge before electrokinetic remediation & $164.47 \pm 0.96$ & $69.15 \pm 3.22$ & $67.30 \pm 2.70$ & $263.00 \pm 0.20$ \\
Sewage Sludge after electrokinetic remediation & $73.31 \pm 1.16$ & $31.21 \pm 3.20$ & $18.51 \pm 1.83$ & $83.69 \pm 3.93$ \\
CONAMA Resolution & 1500 & 1000 & 300 & 2800 \\
\hline
\end{tabular}

\section{Electroremediation Assays}

Table 4 presents the decrease in the concentration and consequent increase in the rate of metal removal with time. Removal extents are obtained in the range $54-71 \%$. The highest removal efficiency was for lead ( $72.49 \%)$, followed by zinc $(68.25 \%)$, copper $(55.42 \%)$ and chromium $(54.87 \%)$.

As shown in Table 4, time is a decisive factor in the electroremoval of metallic species. Guaracho (2005) studied the effect of time, concentration of contaminants and applied potential on the efficiency of metal removal. According to the author, the final concentration of metallic species is smaller the higher the applied potential and duration of the electroremoval process. Likewise, the higher the applied potential, the shorter the time required for electroremoval of metals.

The removal efficiency is also related to the availability of metallic species in the sludge. Heavy metals occur in sewage sludge in various forms (Kim et al., 2002). These forms differ in their speciation and mobility, which have a significant impact on the removal efficiency of heavy metals (Kim and Kim, 2001). The values of organic carbon and total nitrogen, as well as the $\mathrm{C} / \mathrm{N}$ ratio, indicate that this sludge contains high levels of nutrients (Table 2). For the electroremoval technique such amounts are unfavorable because they indicates that the metals present can adhere to the organic material, so their removal is more difficult.

Table 4: Decay of the concentration $\left(\mathrm{mg}^{\mathrm{kg}} \mathrm{kg}^{-1}\right)$ on a dry basis and percentages of removal of the metals monitored over time (h) and the respective RSD (\%).

\begin{tabular}{|c|c|c|c|c|}
\hline \multirow{2}{*}{ Time } & \multicolumn{2}{|c|}{ Copper } & \multicolumn{2}{|c|}{ Chromium } \\
\hline & Concentration & Removal & Concentration & Removal \\
\hline $\mathbf{0}$ & $164.47 \pm 0.96$ & 0 & $69.15 \pm 3.22$ & 0 \\
\hline 8 & $153.75 \pm 0.70$ & $6.50 \pm 0.70$ & $56.46 \pm 2.30$ & $18.35 \pm 2.30$ \\
\hline 16 & $128.10 \pm 2.09$ & $22.10 \pm 2.09$ & $49.80 \pm 0.95$ & $27.98 \pm 0.95$ \\
\hline 24 & $108.62 \pm 1.13$ & $33.94 \pm 1.13$ & $50.13 \pm 0.32$ & $27.50 \pm 0.32$ \\
\hline 32 & $112.29 \pm 1.55$ & $31.71 \pm 1.55$ & $45.40 \pm 2.02$ & $34.35 \pm 2.02$ \\
\hline 40 & $73.31 \pm 1.16$ & $55.42 \pm 1.16$ & $31.21 \pm 3.20$ & $54.87 \pm 3.20$ \\
\hline \multirow{2}{*}{ Time } & \multicolumn{2}{|c|}{ Lead } & \multicolumn{2}{|c|}{ Zinc } \\
\hline & Concentration & Removal & Concentration & Removal \\
\hline $\mathbf{0}$ & $67.30 \pm 2.70$ & 0 & $263.00 \pm 0.20$ & 0 \\
\hline 8 & $50.06 \pm 1.26$ & $25.63 \pm 1.26$ & $249.02 \pm 0.71$ & $5.54 \pm 0.71$ \\
\hline 16 & $39.76 \pm 1.06$ & $40.94 \pm 1.06$ & $158.58 \pm 2.17$ & $39.84 \pm 2.17$ \\
\hline 24 & $39.51 \pm 1.54$ & $41.29 \pm 1.54$ & $122.17 \pm 2.86$ & $53.65 \pm 2.86$ \\
\hline 32 & $38.20 \pm 2.00$ & $43.24 \pm 2.00$ & $125.01 \pm 2.92$ & $52.58 \pm 2.92$ \\
\hline 40 & $18.51 \pm 1.83$ & $72.49 \pm 1.83$ & $83.69 \pm 3.93$ & $68.25 \pm 3.93$ \\
\hline
\end{tabular}


The fractionation of metals in certain phases follows several procedures, and the method developed by Tessier et al. (1979) is considered to be one of the most widespread, in which the metal elements are divided into exchangeable/weakly adsorbed phases, bound to carbonates, bound to iron and manganese oxides, bound to organic material and residual material. The easily exchangeable metallic species are more readly removed than those associated with carbonates, oxides and organic matter which, on the other hand, are more easily removed than the species in residual material (inert). The reason that higher rates of removal for lead and zinc are observed is probably due to the way these metals are available in the sludge, more easily removable than copper and chromium.

Table 5 (adapted from Babel and Dacera (2005)) shows the distribution of metals (\%) copper, chromium, lead and zinc attached to each fraction in sewage sludge from three different studies. Dacera e Babel (2007) found that copper and chromium were present in greater quantity in the residual form $(81 \%$ and $95 \%$, respectively), while lead and zinc were mostly associated with the organic matter $(60 \%$ and $44 \%$, respectively). This distribution is similar to that reported by Ali (1994) who found that copper and chromium were present in greater quantity in the residual form (62.58\% and $73.01 \%$, respectively), while lead was mostly bound to carbonates $(51.57 \%)$ and zinc bound to organic matter $(65.84 \%)$. As for Ratanachoo (1995), the same metals were all more available associated to organic matter, ranging from $45 \%$ (copper) to $59 \%$ (chrome).

Another influencing factor is the $\mathrm{pH}$ of the system. The behavior of the $\mathrm{pH}$ in the cathodic region (output of the electrochemical reactor) over time is shown in Figure 2. Figure 2 shows a large variation in the $\mathrm{pH}$ of the cathodic region in the time period studied. Rutigliano et al. (2008) observed that an initially low $\mathrm{pH}$ favored electroremoval. This happens because acidic $\mathrm{pH}$ promotes the release of metallic species in the medium. Guaracho (2005) noted that, for larger values of the potential, there is greater variation in the $\mathrm{pH}$, which was also observed by Pedrazzoli (2004) while working with applied potentials from 10 to $30 \mathrm{~V}$.

Table 5: Distribution of the metals (\%) copper, chromium, lead and zinc attached to each fraction in sewage sludge from three different studies (adapted from Babel and Dacera, 2005).

\begin{tabular}{|c|c|c|c|}
\hline & Dacera e Babel (2007) & Ali (1994) & Ratanachoo (1995) \\
\hline Copper & $\begin{array}{l}\text { Residual }(81 \%) \\
\text { Organic matter }(14 \%) \\
\text { Carbonates }(3 \%) \\
\text { Exchangeable and adsorbed }(2 \%)\end{array}$ & $\begin{array}{l}\text { Residual }(62.58 \%) \\
\text { Carbonates }(20.55 \%) \\
\text { Organic matter }(13.55 \%)\end{array}$ & $\begin{array}{l}\text { Organic matter }(45 \%) \\
\text { Residual }(19 \%) \\
\text { Adsorbed }(16 \%) \\
\text { Carbonates }(12 \%) \\
\text { Exchangeable }(8 \%)\end{array}$ \\
\hline Chromium & $\begin{array}{l}\text { Residual }(95 \%) \\
\text { Organic matter }(5 \%)\end{array}$ & $\begin{array}{l}\text { Residual }(73.01 \%) \\
\text { Organic matter }(17.39 \%) \\
\text { Carbonates }(8.7 \%)\end{array}$ & $\begin{array}{l}\text { Organic matter }(59 \%) \\
\text { Residual }(20 \%) \\
\text { Carbonates }(16 \%) \\
\text { Adsorbed }(4 \%) \\
\text { Exchangeable }(1 \%)\end{array}$ \\
\hline Lead & $\begin{array}{l}\text { Organic matter }(60 \%) \\
\text { Residual }(38 \%) \\
\text { Oxides }(1 \%) \\
\text { Carbonates }(1 \%)\end{array}$ & $\begin{array}{l}\text { Carbonates }(51.57 \%) \\
\text { Organic matter }(33.96 \%) \\
\text { Residual }(11.32 \%) \\
\text { Exchangeable }(2.52 \%) \\
\text { Adsorbed }(0.63 \%)\end{array}$ & $\begin{array}{l}\text { Organic matter }(57 \%) \\
\text { Carbonates }(21 \%) \\
\text { Adsorbed }(9 \%) \\
\text { Exchangeable }(8 \%) \\
\text { Residual }(6 \%)\end{array}$ \\
\hline Zinc & $\begin{array}{l}\text { Organic matter }(44 \%) \\
\text { Carbonates }(20 \%) \\
\text { Oxides }(20 \%) \\
\text { Residual }(14 \%) \\
\text { Exchangeable and adsorbed }(3 \%)\end{array}$ & $\begin{array}{l}\text { Organic matter }(65.84 \%) \\
\text { Carbonates }(22.06 \%) \\
\text { Residual }(11.32 \%) \\
\text { Adsorbed }(0.41 \%) \\
\text { Exchangeable }(037 \%)\end{array}$ & $\begin{array}{l}\text { Organic matter }(58 \%) \\
\text { Exchangeable }(19 \%) \\
\text { Residual }(9 \%) \\
\text { Carbonates }(7 \%) \\
\text { Adsorbed }(7 \%)\end{array}$ \\
\hline
\end{tabular}


According to Figure 2 there is a decrease in the $\mathrm{pH}$ values in the first 24 hours of the experiment. This behavior, similar to the one seen by Matsumoto et al. (2007), may be associated with removal of hydroxyl groups formed at the cathode by the metallic species, with the formation of insoluble hydroxides. Between 24 hours and 32 hours, there is a steadystate $\mathrm{pH}$. Table 4 shows that this period also corresponds to a steady-state for the removal of metals. In the last 8 hours of the experiment, there is an increasing $\mathrm{pH}$, probably due to the lower availability of metallic species in the system. However, during this same period a greatly increased removal efficiency was observed, indicating that the increase in $\mathrm{pH}$ was not significant for favoring the mobilization of metallic species and a consequent decrease in removal efficiency.

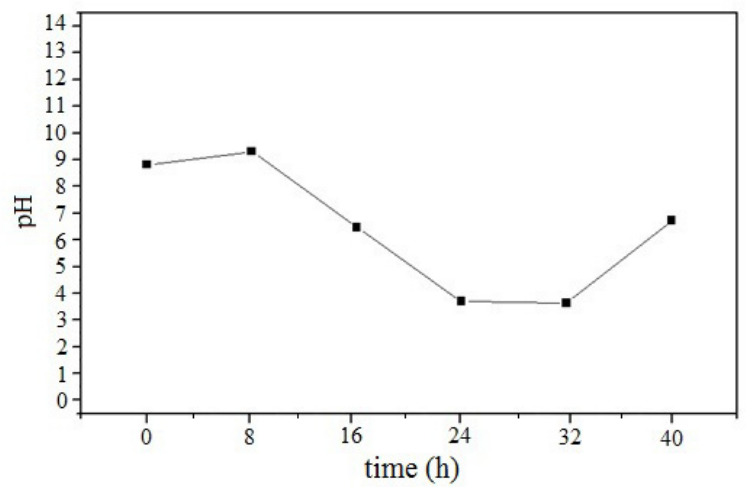

Figure 2: $\mathrm{pH}$ variation in the cathodic sector over time.

\section{CONCLUSIONS}

The electrokinetic process adopted in this study was effective for metal removal from the sludge of a sewage treatment station. In the conditions studied, the percentage removal for all the metals monitored was over $50 \%$. The highest removal efficiency was observed for lead $(72.49 \%)$ and the lowest for chromium $(54.87 \%)$. The results showed the feasibility of the application of the electrochemical technique of electrokinetic remediation for metal removal from sludge sewage treatment station.

\section{NOMENCLATURE}

\section{Acronyms and Abbreviations}

ABNT Associação Brasileira de Normas

Técnicas (Brazilian Association

of Technical Standards)

$\begin{array}{ll}\text { CONAMA } & \begin{array}{l}\text { Conselho Nacional do Meio } \\ \text { Ambiente (National Environment } \\ \text { Council) }\end{array} \\ \text { ETE } & \begin{array}{l}\text { Estação de Tratamento de } \\ \text { Efluentes (Sewage Treatment } \\ \text { Station) }\end{array} \\ \text { NBR } & \begin{array}{l}\text { Norma Brasileira (Brazilian } \\ \text { Standard) }\end{array} \\ \text { RALF } & \begin{array}{l}\text { Reator Anaeróbio de Leito } \\ \text { Fluidizado (Anaerobic Fluidized } \\ \text { Bed Reactor) } \\ \text { Relative Standard Deviations (\%) }\end{array} \\ \text { RSD } & \end{array}$

\section{REFERENCES}

ABNT, Brazilian Association of Technical Standards (ABNT). NBR 10004. Classificação dos Resíduos Sólidos (1987). (In Portuguese).

Acar, Y. B., Alshawabkeh, A. N., Principles of electrokinetic remediation. Environ. Sci. Technol., 27 (13), p. 2638-2647 (1993).

Ali, S. M., Chemical and Biological Heavy Metal Dissolution Process for Sewage Sludge. Master's Thesis. Asian Institute of Technology (1994).

Babel, S., Dacera, D. M., Heavy metal removal from contaminated sludge for land application: A review. Waste Management. 26(9), p. 988-1004 (2005).

Baird, C., Química Ambiental. 2 ${ }^{\mathrm{a}}$ Ed. Porto Alegre, Bookman (2002). (In Portuguese).

CONAMA, National Council of the Environment. Resolution $\mathrm{n}^{\circ} 375$. Criteria and procedures for the agricultural use of sewage sludge generated by sewage treatment sewage and their derivative products (2006).

Dacera, D. D. M., Babel, S., Removal of heavy metals from contaminated sewage sludge using Aspergillus niger fermented raw liquid from pineapple wastes. Bioresearch Tech., 99(6), p. 1682-1689 (2007).

Dias, J. C., Lima, W. N., Method comparison for determining organic matter in environmental samples. Scientific Journal of UFPA. v. 4, 2004. Available in: $<$ http://www2.ufpa.br/rcientifica/ed anteriores/pdf/ed_04_jcd.pdf $>$ (Accessed: November 13, 2013).

Guaracho, V. V., Electrokinetic remediation of lead and nickel in landfarming soils of refinery. Master's Thesis, Federal University of Paraná (2005).

Hortellani, M. A., Sarkis, J. E. S., Abessa, D. M. S., Sousa, E. C. M., Evaluation of the contamination by metallic elements in estuary sediment in Santos São Vicente. Quim. Nova, 31(1), p. 10-19 (2008).

Kim, K.-J. Kim, D.-H., Yoo, J.-C., Baek, K., Electrokinetic extraction of heavy metals from dredged 
marine sediment. Separation and Purification Tech., 79(2), p. 164-169 (2011).

Kim, S. O., Kim, K. W., Monitoring of electrokinetic removal of heavy metals in tailing-soils using sequential extraction analysis. J. Hazard. Mater., 85(3), p. 195-211 (2001).

Kim, S. O., Moon, S. H., Kim, K. W., Yun, S. T., Pilot scale study on the ex situ electrokinetic removal of heavy metals from municipal wastewater sludges. Water Res., n. 36 (2002).

Matsumoto, N., Hiroaki, U., Saiki, H., Case study of electrochemical metal removal from actual sediment, sewage and scallop organs and subsequent $\mathrm{pH}$ adjustment of sediment for agricultural use. Water Research., 41(12), p. 2541-2550 (2007).

Niroumand, H., Nazir, R., Kassim, K. A., The Performance of Electrochemical Remediation Technologies in Soil Mechanics. Int. J. Electrochem. Sci., 7(6), p. 5708-5715 (2012).

Pamukcu, S., Wittle, J. K., Electrokinetic removal of selected heavy metals from soil. Environmental Program, 11(3), p. 241-250 (1992).

Pedrazzoli, C. D., Electrokinetic Remediation of Lead in Industrial Waste. Master's Thesis, Federal University of Paraná (2004).

Probstein, R. F., Hicks, R. E., Removal of contaminants from soils by electric fields. Science, 260 (5107), p. 498-503 (1993).

Rajeshwar, K., Ibanez, J. G., Environmental Electrochemistry. S. Diego. Academic Press (1997).

Ratanachoo, K., Biological Heavy Metal Removal from Sewage Sludge. Master's Thesis, Asian Institute of Technology (1995).
Rozas, F., Castellote, M., Electrokinetic remediation of dredged sediments polluted with heavy metals with different enhancing electrolytes. Electrochimica Acta, 86, p. 102-109 (2012).

Rutigliano, L., Fino, D., Saracco, G., Spdcchia, V., Spinelli, P., Electrokinetic remediation of soils contaminated with heavy metals. Journal of Applied Electrochemistry, 38(7), p. 1035-1041 (2008).

Schmidt, C. A. B., Application of the Electrokinetic Technique in the Laboratory in Two Types of Clay Soils. PhD Thesis, Federal University of Rio de Janeiro (2004).

Tavares, T. M., Carvalho, F. M., Assessment of exposure of human populations to heavy metals in the environment: Examples of Recôncavo Baiano. Quím. Nova, 15(2), p. 147-154 (1992).

Tedesco, M. J., Gianello, C., Bissani, C. A., Bohnen, H., Volkweiss, S. J., Analysis of soil, plants and other materials. Technical Bulletin No. 5, 2nd Ed., Federal University of Rio Grande do Sul (1995).

Tessier, A., Campbell, P. G. C., Bisson, M., Sequential extraction procedure for the speciation of particulate trace metals. Analytical Chemistry, 51(7), p. 844-851 (1979).

Thaveemaitree, Y., Polprasert, C., Seunghwan, L., Application of electrochemical process for landfill leachate treatment with emphasis on heavy metal and organic removal. Environmental Technology, 24(9), p. 1135-1145 (2003).

Zhongming, L., Yu, J., Neretnieks, I., A new approach to electrokinetic remediation of soils polluted by heavy metals. Journal of Contaminant Hydrology, 22(3-4), p. 241-253 (1996). 